\title{
Synthesis and Characterization of Copoly(succinic anhydride-ethylene oxide) -Poly(L-lactide) Block Copolymer
}

\author{
Yasukatsu MAEdA, ${ }^{\dagger}$ Atsuyoshi NAKaYAma, ${ }^{*}$ Ioannis ARvanitoyannis, ${ }^{* *}$ Norioki KaWASAKI, ${ }^{*}$ \\ Kazuko HaYASHI, * Noboru Yamamoto, ${ }^{*}$ and Seiichi AIBA* \\ Industrial Technology Center of Wakayama Prefecture, WINTEC, Department of Material Technology, \\ 60 Ogura, Wakayama 649-6261, Japan \\ * Osaka National Research Institute, AIST, Department of Organic Materials, \\ 1-8-31 Midorigaoka, Ikeda, Osaka 563-8577, Japan \\ **Aristotelian University of Thessaloniki, Faculty of Agriculture, \\ Department of Food \& Science Technology, \\ Box 26554006 Thessaloniki, Greece
}

(Received February 17, 1999)

\begin{abstract}
The polymerization of L-lactide (LA) was carried out in the presence of tin (II) 2-ethylhexanoate, Sn$(\mathrm{Oct})_{2}$ and copoly[succinic anhydride (SA)-ethylene oxide (EO)] which has a hydroxyl end group. The synthesized copolymers were characterized by GPC, ${ }^{1} \mathrm{H}$ NMR, ${ }^{13} \mathrm{C}$ NMR, and DSC. The products were block copolymers consisting of copoly(SA-EO) and poly(L-lactide) (PLA) segments. Optical micrographs of the copolymer films confirmed the presence of spherulitic morphology. Spherulite size was enhanced with increase in the LA content in the copolymers. The block copolymers were hydrolyzed with or without lipase and biodegraded by enzymes from microorganisms in activated sludge. Hydrolyzability decreased with increase in LA content in the block copolymers. The solubility of the block copolymers containing LA segment in tetrahydrofuran (THF) was higher than that of copoly(SA-EO).
\end{abstract}

KEY WORDS Poly(L-lactide)/Synthesis / Block Polymer/Biodegradable /

Biodegradable polymers are promising materials for alleviating plastic industrial and household waste.

Several biodegradable polymers such as $\operatorname{poly}(\varepsilon-$ caprolactone) (PCL) ${ }^{1}$ poly(butylene succinate) (PBS), ${ }^{2}$ and polylactides (or polylactic acids), ${ }^{3-9}$ produced through organic synthesis, have already been on the market or are on the point of being commercialized. Recently, poly(L-lactide)(PLA) has become a major research subject for many groups of researchers because of its satisfactory degradability, its high tensile strength and a high melting point (above $170^{\circ} \mathrm{C}$ ) compared to other aliphatic polyesters such as PCL and PBS. The monomer and degradation products are not toxic for many vital functions. These properties are suitable not only for biomedical applications, e.g., as materials for controlled release of drugs and sutures, ${ }^{10-13}$ but also for every day necessaries. However, to improve properties such as impact strength, biodegradability and hydrophilicity, block copolymers containing PLA segment have been studied.

Block copolymers may serve as emulsifiers for the blends of biodegradable homopolymers. Therefore, the study of such copolymers is of great interest. Diblock copolymers can be used to decrease the size of the blend component domains, and interfacial tension and improve the mechanical properties of immiscible polymer blends. Polyethers, ${ }^{14-22}$ PCL, ${ }^{23-30}$ and poly(hydroxybutylate) $(\mathrm{PHB})^{31}$ having hydroxyl end group have been block copolymerized with PLA. Block copolymers are produced by a polymerization of LA in the presence of one of the above polymers using $\mathrm{Sn}(\mathrm{Oct})_{2}$ or triethyl aluminum as catalyst. A transesterification between two different polymers may result in a new block copolymer. ${ }^{22,23}$ Gross et al. ${ }^{18}$ reported the production of poly-
(PLA-block-polyethylene oxide) under random polymerization conditions.

We reported the polycodensation of polyether and copoly[succinic anhydride (SA)-ethylene oxide (EO)] to prepare a biodegradable block copolyesterether and study the relationship between the biodegradability or thermal properties and length of polymer segments. ${ }^{32-35}$ Polycondensation between copoly(SA-EO) and polypropylene glycol or triblock (polyethylene oxide-polypropylene glycol- polyethylene oxide) really improved elongation while retaining the biodegradability of copoly(SAEO) ${ }^{35}$ However, the tensile strength was lower than that of low density polyethylene (LDPE) and the melting point was below $100^{\circ} \mathrm{C}$. One expected method for improving the mechanical and thermal properties of the copolymer is to introduce the PLA segment into the copoly(SAEO) segment.

To the best of our knowledge, there have been no reports on a block copolymer consisting of a polyester having succinic acid or SA and PLA except for the polymer composed of D,L-lactide and fumaric acid. ${ }^{36}$ In this study, LA was polymerized in the presence of copoly(SA-EO) having an end-hydroxyl group and $\mathrm{Sn}(\mathrm{Oct})_{2}$. Poly[copoly(SA-EO)-block-PLA] obtained were characterized using GPC, ${ }^{1} \mathrm{H}$ NMR, ${ }^{13} \mathrm{C}$ NMR, and DSC. The hydrolyzability was evaluated with or without lipase and effects of the segment length in the block copolymer on their hydrolyzability, and thermal properties were studied.

\section{EXPERIMENTAL}

\section{Materials}

SA (from Wako Pure Chemical Co. Japan) was recrys-

\footnotetext{
${ }^{\dagger}$ To whom all correspondence should be addressed (Tel: +81-734-77-1271, Fax: +81-734-77-2880)
} 
tallized from chloroform, $\left(\mathrm{CHCl}_{3}\right)$. EO (from Sumitomo Seika Co. Japan) was purified with a trap to trap method on calcium hydride under reduced pressure. LA and D,L-lactide were purchased from Purac Biochem BV, Gorinchem. Magnesium diethoxide, $\left[\mathrm{Mg}(\mathrm{OEt})_{2}\right]$, triethyl aluminum $\left(\mathrm{AlEt}_{3}\right), \mathrm{Sn}(\mathrm{Oct})_{2}$ (from Wako Pure Chemical Co. Japan) were used as received. The enzyme for biodegradation was a lipase from Rhizopus arrhizus (Boehringer Mannheim). Standard activated sludge was provided from Chemical Inspection \& Testing Institute, Japan. A series of copoly(SA-EO)s $\left(M_{n}=2600-13000\right)$ were prepared by a ring-opening copolymerization using $\mathrm{Mg}(\mathrm{OEt})_{2}$ described in our previous paper. ${ }^{32}$ The NMR assignment of the copolymers is as follows. ${ }^{1} \mathrm{H}$ NMR $\delta$ $(\mathrm{ppm}): 2.67\left(\mathrm{~s}, 4 \mathrm{H},-S A^{-}\right), 3.65\left(\mathrm{~s}, 4 \mathrm{H},-\mathrm{EO}-E O^{-} \mathrm{EO}-\right)$, $3.69(\mathrm{t}, 2 \mathrm{H},-\mathrm{SA}-E O-\mathrm{EO}-$ or $-\mathrm{EO}-E O-\mathrm{SA}-), 4.25(\mathrm{t}, 2 \mathrm{H}$, -SA-EO-EO- or -EO-EO-SA-), $4.30(\mathrm{~s}, 4 \mathrm{H},-\mathrm{SA}-E O$ $\mathrm{SA}-), 1.27\left(\mathrm{t}, 3 \mathrm{H},-\mathrm{COOCH}_{2} \mathrm{CH}_{3}\right), 3.82\left(\mathrm{t}, 2 \mathrm{H},-\mathrm{COOCH}_{2}-\right.$ $\left.\mathrm{CH}_{2} \mathrm{OH}\right), 4.16\left(\mathrm{q}, 2 \mathrm{H},-\mathrm{COOCH}_{2} \mathrm{CH}_{3}\right){ }^{13} \mathrm{C} \mathrm{NMR}\left(\mathrm{CDCl}_{3}\right)$, $\delta(\mathrm{ppm}): 28.90\left(-\mathrm{SA}^{-},-\mathrm{CH}_{2}{ }^{-}\right), 172.00$ [-SA-, $-\mathrm{OC}(=$ O)-], 70.50 (-EO-EO-EO-, $\left.-\mathrm{CH}_{2}^{-}\right), 68.99$ [-SA-EO$\mathrm{EO}-,-\mathrm{COOCH}_{2} \mathrm{CH}_{2} \mathrm{O}^{-}$or $-\mathrm{EO}-\mathrm{EO}-\mathrm{SA}^{-},-\mathrm{OCH}_{2} \mathrm{CH}_{2} \mathrm{OC}$ $(=\mathrm{O})^{-}$], 63.74 [-SA-EO-EO-, $-\mathrm{COOCH}_{2} \mathrm{CH}_{2} \mathrm{O}^{-}$or $-\mathrm{EO}-$ $\left.E O-\mathrm{SA}-, \quad-\mathrm{OCH}_{2} \mathrm{CH}_{2} \mathrm{OC}(=\mathrm{O})-\right], 62.37$ (-SA-EO-SA-, $\left.-\mathrm{CH}_{2}{ }^{-}\right), 60.72\left(-\mathrm{COOCH}_{2} \mathrm{CH}_{2} \mathrm{OH}\right), 66.35\left(-\mathrm{COOCH}_{2} \mathrm{CH}_{2}\right.$ $\mathrm{OH}), 14.17\left(-\mathrm{COOCH}_{2} \mathrm{CH}_{3}\right), 60.75\left(-\mathrm{COOCH}_{2} \mathrm{CH}_{3}\right)$ However, ${ }^{13} \mathrm{C}$ NMR signals of ethoxy end group were not detectable when the $M_{n}$ of these copolymers were more than 4200 .

\section{Synthesis of Copoly(SA-EO)-PLA Block Copolymer(Sch-} eme)

Copoly(SA-EO) $(1 \mathrm{~g}), \mathrm{LA}$ and $\mathrm{Sn}(\mathrm{Oct})_{2}(0.01 \mathrm{~g})$ were put into an ampule. The feed weight ratio, LA/copoly(SA-EO) $(\mathrm{w} / \mathrm{w})$ was 0.5 to 2.7 . The polymerization temperature ranged from $110(19 \mathrm{~h})$ to $170^{\circ} \mathrm{C}(2.5 \mathrm{~h})$. The polymerization products were dissolved in $\mathrm{CHCl}_{3}$ and insoluble materials were removed by filtration. The $\mathrm{CHCl}_{3}$ solution was concentrated in vacuo and the polymers were precipitated with petroleum ether and dried under vacuum at $80^{\circ} \mathrm{C}$ for $24 \mathrm{~h}$.

To clarify the mechanism of the LA polymerization in the presence of copoly(SA-EO) and $\mathrm{Sn}(\mathrm{Oct})_{2}$, LA polymerization without $\mathrm{Sn}(\mathrm{Oct})_{2}$ was carried out. Copoly(SA$\mathrm{EO})$ and $\mathrm{Sn}(\mathrm{Oct})_{2}$ were reacted without LA under the same conditions above described. For comparison, PLA, poly(D,L-lactide), and terpoly(SA-EO-LA) were synthesized under similar conditions.

Blends of PLA and copoly(SA-EO) (feed weight ratio of PLA/copoly(SA-EO) ; 75/25 and 50/50) were prepared as follows : Both polymers were dissolved in $\mathrm{CHCl}_{3}$, and reprecipitated by petroleum ether. The polymer blend was dried under vacuum at $80^{\circ} \mathrm{C}$ for $24 \mathrm{~h}$

\section{Preparation of Films}

Film specimens (thickness : $50-100 \mu \mathrm{m}$ ) were prepared by compression molding of polymer powder or flake using a laboratory press (G-12, Techno Supply Co., Ltd., Japan) at $5^{\circ} \mathrm{C}$ higher than the melting temperature of the copolymers for $30 \mathrm{~s}$ at $50 \mathrm{~kg} \mathrm{~cm}^{-2}$. The prepared films were aged for $1 \mathrm{~h}$ at $100^{\circ} \mathrm{C}$ to reach equilibrium crystallinity.
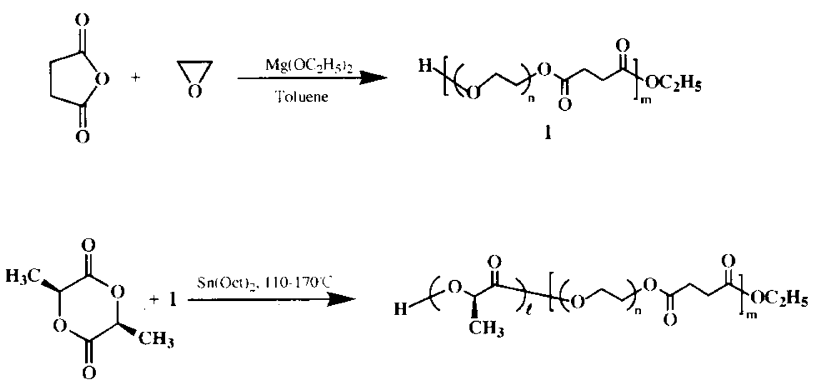

Scheme.

\section{Hydrolysis with Enzyme and without Enzyme}

Enzymatic hydrolysis was carried out as follows: Twenty five mg of polymer samples (powder or flake and film) and $2 \mathrm{~mL}$ of phosphate buffer $\left(\mathrm{KH}_{2} \mathrm{PO}_{4} / \mathrm{Na}_{2} \mathrm{HPO}_{4}\right.$, $\mathrm{pH}$ 7.0) were placed in a test tube, and prescribed units of enzyme were added. Blank tests were conducted for the polymers suspended without enzyme and for the enzyme itself. The enzyme used was a lipase from Rhizopus arrhizus. Enzymatic hydrolysis was carried out at $37^{\circ} \mathrm{C}$ for a fixed time. After filtration $(0.2 \mu \mathrm{m}$ membrane filter), total organic carbon (TOC) of the filtrate was measured with a TOC analyzer (Shimadzu TOC 500). Net TOC were calculated by subtracting the average values at the two control tests from the average of two measurements.

Hydrolysis without enzyme was performed at $70^{\circ} \mathrm{C}$ in distilled water for 5 days and the control test was carried out at $30^{\circ} \mathrm{C}$ under the same conditions. TOC measurements were carried out by the same method as hydrolysis with enzyme.

\section{Degradation by Activated Sludge}

A schematic diagram of the apparatus for an aerobic degradation was described in detail elsewhere. ${ }^{37}$ The supernatant ( $30 \mathrm{~mL}$, MLSS, $30 \mathrm{mg}$ ) of standard activated sludge and a polymer film sample $(0.2 \mathrm{~g})$ were placed in a fermenter containing a carbon-free culture medium (500 mL, pH 7.0) according to ASTM D 5209-92. The fermenter was incubated at $30^{\circ} \mathrm{C}$, aerated with $\mathrm{CO}_{2}-$ free air under magnetic stirring. The evolved $\mathrm{CO}_{2}$ was absorbed into a $0.5 \%$ sodium hydroxide solution and determined by inorganic carbon concentration (IC) measurement for the alkaline solution with a TOC analyzer at every definite time until the evolution rate reached a plateau. Biodegradation (\%) of polymers was calculated from the following equation :

$$
\text { Biodegradation }(\%)=\frac{\text { Experimentally measured } \mathrm{CO}_{2}}{\text { Theoretical } \mathrm{CO}_{2}} \times 100
$$

Theoretically released $\mathrm{CO}_{2}$ was calculated from the chemical structural formula of these copolymers, assuming that oligomers or monomers, initially formed by enzymatic hydrolysis were completely mineralized to $\mathrm{CO}_{2}$.

\section{Analytical Procedures}

Characterization of Copolymers. ${ }^{1} \mathrm{H}$ and ${ }^{13} \mathrm{C} \mathrm{NMR}$ spectra were recorded on a Varian UNITYplus-400 spectrometer (400 MHz and $100.57 \mathrm{MHz}$, respectively). All spectra were obtained from chloroform-d solutions at room temperature with tetramethylsilane (TMS) as the 
Copoly(succinic anhydride-ethylene oxide)-Poly(L-lactide) Copolymer

Table I. Copolymerization results of L-lactide with copoly(SA-EO) ${ }^{\text {a }}$

\begin{tabular}{|c|c|c|c|c|c|c|c|c|c|c|c|c|}
\hline \multirow{3}{*}{ Run } & \multicolumn{3}{|c|}{ Starting materials } & \multicolumn{4}{|c|}{ Polymerization conditions } & \multicolumn{5}{|c|}{ Obtained polymer } \\
\hline & \multirow{2}{*}{$\begin{array}{l}\text { Lactide } \\
\text { (LD) }\end{array}$} & \multicolumn{2}{|c|}{ Copoly(SA-EO) } & \multirow{2}{*}{$\begin{array}{c}\text { Feed ratio } \\
\text { LA/Copoly(SA-EO) } \\
(\mathrm{w} / \mathrm{w}) \\
\end{array}$} & \multirow[b]{2}{*}{ Catalyst } & \multirow{2}{*}{$\frac{\text { Temp. }}{{ }^{\circ} \mathrm{C}}$} & \multirow{2}{*}{$\frac{\text { Time }}{\mathrm{h}}$} & \multirow{2}{*}{$\frac{\text { Yield }}{\%}$} & \multicolumn{2}{|c|}{ Comp. of obtained polym. } & \multirow{2}{*}{$\begin{array}{c}M_{n}^{\mathrm{d}} \\
\left(\times 10^{-3}\right) \\
\end{array}$} & \multirow[b]{2}{*}{$M_{w} / M_{n}^{\mathrm{d}}$} \\
\hline & & $\begin{array}{c}\text { Comp. }[\mathrm{SA}] /[\mathrm{EO}] \\
\text { (molar ratio) }\end{array}$ & $\begin{array}{c}M_{n} \\
\left(\times 10^{-3}\right) \\
\end{array}$ & & & & & & $\begin{array}{c}{[\mathrm{L} / / \text { Copoly(SA-EO) }]^{\mathrm{b}}} \\
\text { (molar ratio) }\end{array}$ & $\begin{array}{c}{[\mathrm{SA}] /[\mathrm{EO}]^{\mathrm{c}}} \\
\text { (molar ratio) }^{-{ }^{2}}\end{array}$ & & \\
\hline 1 & L- & $48 / 52$ & 6.3 & $73 / 27$ & $\mathrm{Sn}(\mathrm{Oct})_{2}$ & 110 & 19 & 84 & $69 / 31$ & $42 / 53$ & 12.3 & 2.8 \\
\hline 2 & L- & $48 / 52$ & 6.3 & $67 / 33$ & $\mathrm{Sn}(\mathrm{Oct})_{2}$ & 110 & 19 & 96 & $56 / 44$ & $44 / 56$ & 11.0 & 2.7 \\
\hline 3 & L- & $48 / 52$ & 4.2 & $50 / 50$ & $\mathrm{Sn}(\mathrm{Oct})_{2}$ & 110 & 19 & 76 & $40 / 60$ & $45 / 55$ & 5.2 & 2.4 \\
\hline 4 & L- & $48 / 52$ & 6.3 & $20 / 80$ & $\mathrm{Sn}(\mathrm{Oct})_{2}$ & 110 & 19 & 82 & $12 / 88$ & $47 / 53$ & 5.6 & 2.7 \\
\hline 5 & L- & $47 / 53$ & 6.7 & $73 / 27$ & $\mathrm{Sn}(\mathrm{Oct})_{2}$ & 145 & 5 & 87 & $62 / 38$ & $44 / 56$ & 19.4 & 2.1 \\
\hline 6 & L- & $47 / 53$ & 6.7 & $67 / 33$ & $\mathrm{Sn}(\mathrm{Oct})_{2}$ & 145 & 5 & 80 & $54 / 46$ & $45 / 55$ & 11.6 & 2.1 \\
\hline 7 & L- & $47 / 53$ & 6.7 & $50 / 50$ & $\mathrm{Sn}(\mathrm{Oct})_{2}$ & 145 & 5 & 86 & $35 / 65$ & $46 / 54$ & 8.1 & 2.1 \\
\hline 8 & L- & $47 / 53$ & 6.7 & $73 / 27$ & $\mathrm{Sn}(\mathrm{Oct})_{2}$ & 170 & 2.5 & 86 & $55 / 45$ & $46 / 54$ & 12.0 & 1.9 \\
\hline 9 & L- & $47 / 53$ & 6.7 & $67 / 33$ & $\mathrm{Sn}(\mathrm{Oct})_{2}$ & 170 & 2.5 & 84 & $58 / 42$ & $47 / 53$ & 9.9 & 1.9 \\
\hline 10 & L- & $47 / 53$ & 6.7 & $50 / 50$ & $\mathrm{Sn}(\mathrm{Oct})_{2}$ & 170 & 2.5 & 80 & $33 / 67$ & $44 / 56$ & 7.3 & 1.9 \\
\hline 11 & $D, L-$ & $48 / 52$ & 6.3 & $73 / 27$ & $\mathrm{Sn}(\mathrm{Oct})_{2}$ & 110 & 19 & 79 & $61 / 39$ & $44 / 56$ & 13.7 & 2.5 \\
\hline 12 & L- & $48 / 52$ & 6.3 & $73 / 27$ & $\mathrm{AlEt}_{3}$ & 110 & 19 & 55 & $47 / 53$ & $47 / 53$ & 7.8 & 3.6 \\
\hline 13 & None & $48 / 52$ & 6.3 & $0 / 100$ & $\mathrm{Sn}(\mathrm{Oct})_{2}$ & 145 & 5 & 98 & $0 / 100$ & $48 / 52$ & 5.4 & 1.9 \\
\hline 14 & L- & $48 / 52$ & 6.3 & $67 / 33$ & None & 145 & 5 & - & $0 / 100$ & $48 / 52$ & 6.4 & 1.9 \\
\hline 15 & L- & - & 一 & $100 / 0$ & $\mathrm{Sn}(\mathrm{Oct})_{2}$ & 110 & 19 & 90 & $100 / 0$ & - & 22.0 & 3.3 \\
\hline
\end{tabular}

${ }^{a}$ Polymerization was carried out using copoly(SA-EO) $(1 \mathrm{~g})$ and Sn $(\text { Oct })_{2}(0.01 \mathrm{~g})$ as a catalyst. ${ }^{\mathrm{b}}$ Determined by ${ }^{1} \mathrm{H}$ NMR. [L] shows Llactic acid unit (a half of LA unit). ${ }^{c}$ Compositions of copoly(SA-EO) segments in block copolymers. ${ }^{\mathrm{d}}$ Determined by GPC measurement (solvent : $\mathrm{CHCl}_{3}$, standard : polystyrene).

internal standard. IR spectra were recorded on a Perkin Elmer 1600 FT-IR spectrometer, using film samples cast on a potassium bromide plate from $\mathrm{CHCl}_{3}$ solutions. Differential scanning calorimetry (DSC) measurements were made with a Seiko Denshi DSC120. The DSC samples varied from 4 to $8 \mathrm{mg}$, and the heating rate was 10 ${ }^{\circ} \mathrm{C} \min ^{-1}$ in the range of temperature from -70 to $120^{\circ} \mathrm{C}$ (first scan). After the first run, the sample was cooled to $-80^{\circ} \mathrm{C}$ at a rate of $c a .10^{\circ} \mathrm{C} \mathrm{min}^{-1}$, followed by second run under the same conditions. Molecular weight $\left(M_{n}\right)$ and weight distributions $\left(M_{w} / M_{n}\right)$ were determined with GPC (TOSOH, HCL-8020). The columns were a TSKgel G4000HXL and a TSKgel G3000HXL with limited exclusion molecular weight of $4 \times 10^{5}$. $\mathrm{CHCl}_{3}$ was used as eluent at a flow rate of $0.6 \mathrm{~mL} \mathrm{~min}^{-1}$. Polystyrene standards with low polydispersity were used to generate a calibration curve. The morphology of each sample was investigated using a Olympus polarizing microscope (Model B 071). Solubility of the copolymers in THF or $\mathrm{THF} / \mathrm{CHCl}_{3}$ was examined at room temperature or $40^{\circ} \mathrm{C}$.

\section{RESULTS AND DISCUSSION}

\section{Polymerization of Lactide}

LA was polymerized in the presence of $\mathrm{Sn}(\mathrm{Oct})_{2}$ and copoly(SA-EO). The results are summarized in Table I. The feed weight ratios, LA/copoly(SA-EO), were varied at $0.25-2.7$. The compositions, $[\mathrm{L}],[\mathrm{SA}]$, and $[\mathrm{EO}]$ in the block copolymers were determined by ${ }^{1} \mathrm{H}$ NMR analysis. [L] shows L-lactic acid unit which is a half of LA monomer unit in the copolymers. The polymerization yields using $\mathrm{Sn}(\mathrm{Oct})_{2}$ as a catalyst were higher than $80 \%$. Table I shows that the composition, $[\mathrm{L}] /[\operatorname{copoly}(\mathrm{SA}-\mathrm{EO})]$, of the obtained copolymers changed with the feed weight ratio of LA monomer and copoly(SA-EO). When the LA monomer in feed was rich, $[\mathrm{L}]$ of the copolymers proportionally increased with LA weight ratio in feed and $M_{n} \mathrm{~s}$ were over 10000 (Run 1, 2 in Table I). There was a similar tendency with change in temperature and the higher temperature shortened the polymerization time. Using
$\mathrm{AlEt}_{3}$ as a catalyst instead of $\mathrm{Sn}(\mathrm{Oct})_{2}$, the polymerization yield was rather low (55\%) and in the absence of catalyst, LA polymerization did not proceed completely (Run 12, 14). The composition, [EO] in the block copolymers was slightly rich compared with that of the original copoly(SA-EO). This suggests that the copoly(SA-EO) as a prepolymer might decompose through LA polymerization. A small amount of succinic anhydride residue was observed in the reaction flask at the end of copolymerization in many cases. The [SA]/[EO] ratios were the same as those of the original copoly(SA-EO) in the absence of LA monomer (Run 13) or Sn(Oct) ${ }_{2}$ (Run 14). Therefore, the decomposition of copoly(SA-EO) seems attributable to LA monomer and $\mathrm{Sn}(\mathrm{Oct})_{2}$, although, the decomposition mechanism of the copoly(SA-EO) is not still clear.

The typical GPC curves of synthesized copolymers are shown in Figure 1. All GPC curves showed unimodal. As LA weight ratio in feed monomers increased, the peak in the GPC curves shifted to higher molecular weight zone. In the case of low weight ratio of LA (a, Run 4 in Table I), the GPC curve was situated in the lower molecular weight zone than that of copoly(SA-EO), (b), supporting that the copoly(SA-EO) is partially decomposed through LA polymerization.

The molecular weights of the block copolymers and copoly(SA-EO)s as prepolymer are summarized in Table II. $M_{n \text { calc. }}$ stands for the $M_{n}$ calculated on the basis of feed weight of LA monomer and polymerization yield. $M_{n \text { calc. }}$ was higher than that determined by GPC measurement $\left(M_{n \text { gpc }}\right)$. The difference between the $M_{n \text { calc. }}$ and the $M_{n \text { gpc }}$ of copolymer seems to be caused not only by the imperfect initiation of LA monomer, but by the decomposition of copoly(SA-EO) through the LA copolymerization. $M_{n}$ PLA $\mathrm{S}$ which represent $M_{n}$ of PLA segment in block copolymer were calculated from the intensity ratio between - $\mathrm{OCH}\left(\mathrm{CH}_{3}\right) \mathrm{CO}^{-}$and $\mathrm{HOCH}\left(\mathrm{CH}_{3}\right) \mathrm{CO}^{-}$in ${ }^{1} \mathrm{H} \mathrm{NMR}$ spectra. In many cases (Run $1,2,6,8,9,11$ and 12 in Table II), $M_{n}$ PLA s were found to be almost half the increase of $\Delta M_{n}\left(\Delta M_{n}=M_{n \text { gpc }}-M_{n 0}\right)\left(M_{n 0}\right.$ means $M_{n \text { gpc }}$ of the 


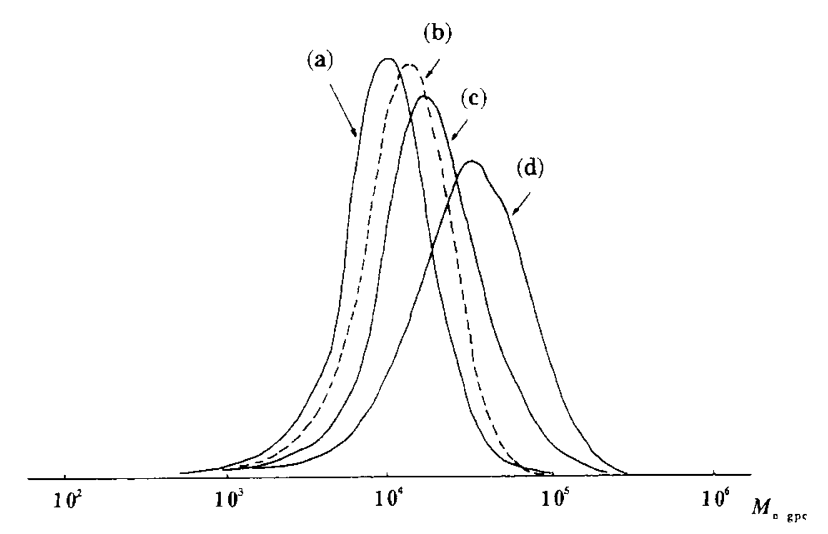

Figure 1. GPC profiles of typical copolymers : (a) ; Polymerized at feed weight ratio, $\mathrm{LA} /$ copoly(SA-EO) $=0.25$ for $19 \mathrm{~h}$ at $110^{\circ} \mathrm{C}$ (Run 4 in Table I), (b) ; Copoly(SA-EO) $\left(M_{n}=6700, M_{u} / M_{n}=2.0\right)$ used as prepolymer in the LA polymerization, (c) ; Polymerized at feed weight ratio, $\mathrm{LA} / \mathrm{copoly}(\mathrm{SA}-\mathrm{EO})=2.0$ for $5 \mathrm{~h}$ at $145^{\circ} \mathrm{C}(\operatorname{Run} 6)$, (d) ; Polymerized at feed weight ratio, LA/copoly(SA-EO) $=2.7$ for 5 $\mathrm{h}$ at $145^{\circ} \mathrm{C}$ (Run 5 ).

original copoly(SA-EO) used as prepolymer.) In Runs 3, 4,7 , and $10, M_{n}$ PLAs were not agreement with $\Delta M_{n} \mathrm{~s}$. These results suggest that the obtained copolymers were ABA type (A ; PLA, B ; copoly(SA-EO)) when the feed ratio of LA monomer is rich, and that the obtained copolymers were $\mathrm{AB}$ or $\mathrm{ABA}$ with a slight decomposition when the LA feed ratio is low.

$M_{w} / M_{n}$ s of the copolymers synthesized at $110^{\circ} \mathrm{C}$ were higher than those of the block copolymers synthesized at $145^{\circ} \mathrm{C}$ or $170^{\circ} \mathrm{C} . T_{\mathrm{m}} \mathrm{s}$ of the block copolymers are higher than the polymerization temperature, $110^{\circ} \mathrm{C}$ as described below. The copolymers are in a solid state during increase in $M_{n}$ of PLA segment. $T_{m}$ of copoly(SA-EO) is lower than $110^{\circ} \mathrm{C}$. Consequently, the LA polymerization system at $110^{\circ} \mathrm{C}$ changes from homogeneous to heterogeneous with LA polymerization.

Figure 2 shows ${ }^{1} \mathrm{H}$ NMR and ${ }^{13} \mathrm{C}$ NMR spectra for the relatively low $M_{n}$ of copolymer $\left(M_{n}=5200\right.$, Run 3 in Table I). ${ }^{1} \mathrm{H}$ NMR and ${ }^{13} \mathrm{C}$ NMR analyses of $\mathrm{PLA}^{39}$ and block copolymer containing PLA block , e.g., poly(ethylene glycol) (PEG)-PLA di- or triblock copolymer, ${ }^{14,17-20}$ PCL-PLA block copolymer, ${ }^{25,26}$ PHB-PLA diblock copolymer $^{31}$ have been reported. The assignments of ${ }^{1} \mathrm{H}$ NMR and ${ }^{13} \mathrm{C}$ NMR spectra in Figure 2 were conducted based on literature data together with copoly(SAEO) (see EXPERIMENTAL Section). ${ }^{1} \mathrm{H}$ NMR spectrum shows signals derived from copoly(SA-EO) segment except for the signals of $-\mathrm{COOCH}_{2} \mathrm{CH}_{3}$ (i in Figure 2) and $-\mathrm{COOCH}_{2} \mathrm{CH}_{2} \mathrm{OH}$. Moreover, from PLA segment, the signals were detected such as $-\mathrm{CH}_{3}, \mathrm{~d}$., $\delta 1.58 \mathrm{ppm}, J=$ $6.8 \mathrm{~Hz},-\mathrm{CH}\left(\mathrm{CH}_{3}\right)^{-}$, q., $\delta 5.16 \mathrm{ppm}, J=7.1 \mathrm{~Hz}$, and -SAEO- $L A-,-\mathrm{CH}_{3}, \mathrm{~d}$., $\delta 1.52 \mathrm{ppm}, J=7.2 \mathrm{~Hz},-\mathrm{CH}\left(\mathrm{CH}_{3}\right)^{-}$, d., $\delta 5.1-5.2 \mathrm{ppm}, J=7.2 \mathrm{~Hz}$, and from end groups of copolymer such as $\mathrm{HOCH}\left(\mathrm{CH}_{3}\right) \mathrm{CO}^{-}$, q., $\delta 4.3-4.4 \mathrm{ppm}$ and $\mathrm{HOCH}\left(\mathrm{CH}_{3}\right) \mathrm{CO}^{-}$, d., $\delta 1.49 \mathrm{ppm}, J=7.2 \mathrm{~Hz}$.

The ${ }^{13} \mathrm{C}$ NMR spectrum shows signals derived from copoly(SA-EO) segment such as $-\mathrm{SA}-,-\mathrm{CH}_{2}-, \delta 28.80$ ppm, $-\mathrm{OC}(=\mathrm{O})-, \delta 171.99 \mathrm{ppm},-\mathrm{SA}-E O-\mathrm{SA}^{-},-\mathrm{CH}_{2}{ }^{-}, \delta$ $62.35 \mathrm{ppm}$, from PLA segment such as $-\mathrm{CH}_{3}, \delta 16.62$ ppm, ${ }^{-} \mathrm{CH}\left(\mathrm{CH}_{3}\right)^{-}, \quad \delta 69.99 \mathrm{ppm},-\mathrm{OC}(=\mathrm{O})^{-}, \quad \delta 169.57$ ppm, from end group of copolymer, $\mathrm{HOCH}\left(\mathrm{CH}_{3}\right) \mathrm{CO}^{-}, \delta$ $66.69 \mathrm{ppm}, \mathrm{HOCH}\left(\mathrm{CH}_{3}\right) \mathrm{CO}^{-}, \delta 20.49 \mathrm{ppm}$, and $-\mathrm{CH}-$
Table II. Molecular weights $\left(M_{n}\right)$ of block copolymers and copoly(SA-EO)s as a prepolymer

\begin{tabular}{rrrrrr}
\multicolumn{6}{c}{ and copoly(SA-EO) as a prepolymer } \\
\cline { 2 - 4 } Run & \multicolumn{5}{c}{$M_{n}\left(\times 10^{-3}\right)$} \\
\cline { 2 - 4 } & $M_{n \text { calc. }}^{\text {a }}$ & $M_{n \text { gpc }}{ }^{\mathrm{b}}$ & $M_{n \text { PLA }}{ }^{\mathrm{c}}$ & $M_{n 0}{ }^{\mathrm{d}}$ & \multicolumn{1}{c}{$\Delta M_{n}{ }^{\mathrm{e}}$} \\
\hline 1 & 20.6 & 12.3 & 3.2 & 6.3 & 6.0 \\
2 & 18.4 & 11.0 & 2.0 & 6.3 & 4.7 \\
3 & 7.4 & 5.2 & 2.5 & 4.2 & 1.0 \\
4 & 8.1 & 5.6 & 0.55 & 6.3 & -0.7 \\
5 & 22.4 & 19.4 & 2.3 & 6.7 & 12.7 \\
6 & 17.4 & 11.6 & 2.0 & 6.7 & 4.9 \\
7 & 12.5 & 8.1 & 1.4 & 6.7 & 1.4 \\
8 & 22.3 & 12.0 & 2.4 & 6.7 & 5.3 \\
9 & 18.0 & 9.9 & 2.6 & 6.7 & 3.2 \\
10 & 12.1 & 7.3 & 1.0 & 6.7 & 0.6 \\
11 & 19.7 & 13.7 & 2.5 & 6.3 & 7.4 \\
12 & 11.0 & 7.8 & 1.9 & 6.3 & 4.7 \\
13 & - & 5.4 & - & 6.3 & -0.9 \\
14 & - & 6.4 & - & 6.3 & 0.1 \\
15 & - & 22.0 & - & - & 22.0 \\
\hline
\end{tabular}

${ }^{a}$ Expected number-average molecular weight calculated from yield and monomer/hydroxyl group ratio. ${ }^{b}$ Determined by GPC measurement. ${ }^{\mathrm{c}} M_{n}$ of PLA segment in block copolymer based on the integration strength ratio, $-\mathrm{CH}\left(\mathrm{CH}_{3}\right) \mathrm{CO}-/ \mathrm{HOCH}\left(\mathrm{CH}_{3}\right) \mathrm{CO}-$ in ${ }^{1} \mathrm{H}$ NMR spectra. ${ }^{\mathrm{d}} M_{n}$ of copoly(SA-EO) as a prepolymer. ${ }^{\mathrm{e}} \Delta M_{n}$ $=M_{n \text { gpc }}-M_{n 0}$.

$\left(\mathrm{CH}_{3}\right) \mathrm{COOCH}_{2} \mathrm{CH}_{2} \mathrm{O}^{-}, \delta 63.71 \mathrm{ppm}$. The last signal indicates the existence of EO-LA bonds in the copolymer. The peak height of $\mathrm{HOCH}\left(\mathrm{CH}_{3}\right) \mathrm{CO}$ - was equivalent to that of $-\mathrm{CH}\left(\mathrm{CH}_{3}\right) \mathrm{COOCH}_{2} \mathrm{CH}_{2} \mathrm{O}-$. The ${ }^{1} \mathrm{H}$ NMR signal of $-\mathrm{COOCH}_{2} \mathrm{CH}_{2} \mathrm{OH}$ ( $\delta 3.81 \mathrm{ppm}, J=6.8 \mathrm{~Hz}$ ) in copoly(SA$\mathrm{EO})$ as a prepolymer was not detectable after copolymerization with LA. These results support the obtained copolymer (Run 3 in Table I) is a block copolymer. The terminal-OH group in the copoly(SA-EO) is important in the LA polymerization with $\mathrm{Sn}(\mathrm{Oct})_{2}$. NMR analysis of such a block copolymer having PLA block, for example PLA-PEG-PLA ${ }^{14,17-20}$ triblock copolymer, PCL-PLA diblock copolymer, ${ }^{23,25,26}$ and PHB-PLA diblock copolymer $^{31}$ has been discussed. However, a block copolymer containing succinic acid unit has not been studied.

By NMR end analysis, the ratio of $A B A / A B$ could be calculated. However, in this case, this is difficult because a) ${ }^{1} \mathrm{H}$ NMR methyl and methyne signals of $\mathrm{OH}$ end unit [HOCH$\left.\left(\mathrm{CH}_{3}\right) \mathrm{CO}^{-}\right]$overlap with other signals (1.52 and $4.3 \mathrm{ppm})$, and b) ${ }^{13} \mathrm{C}$ NMR signals of ethyl ester end unit are not quantitatively clarified against noise. At first, we presumed that an $\mathrm{AB}$ block copolymer could be obtained in the presence of copoly(SA-EO) having one $\mathrm{OH}$ endgroup. However, ABA type block copolymers were synthesized in many cases. This suggests that reactive $\mathrm{OH}$ groups at both ends derived from copoly (SA-EO) may be produced by the decomposition of copoly(SA-EO).

The mechanism of LA polymerization in the presence of $\mathrm{Sn}(\mathrm{Oct})_{2}$ and a polymer having $\mathrm{OH}$-end group (or alcohol) as a macroinitiator has been investigated by Kricheldorf et $a l .{ }^{38}$ and Nijenhuis et al. ${ }^{39}$ Their polymerization mechanisms differ in formation of coordination compounds at the initiation step in the LA polymerization. Kricheldorf et al. proposed that the coordination compound between $\mathrm{Sn}(\mathrm{Oct})_{2}$ and $\mathrm{OH}$-end group is formed at first, followed by insertion of LA monomer into the coordination compound. Nijenhuis et al. suggest the formation of the coordination compound between $\mathrm{Sn}$ $(\mathrm{Oct})_{2}$ and LA, followed by reaction of $\mathrm{OH}$-end group and 


\section{${ }^{1} \mathrm{H}$ NMR}
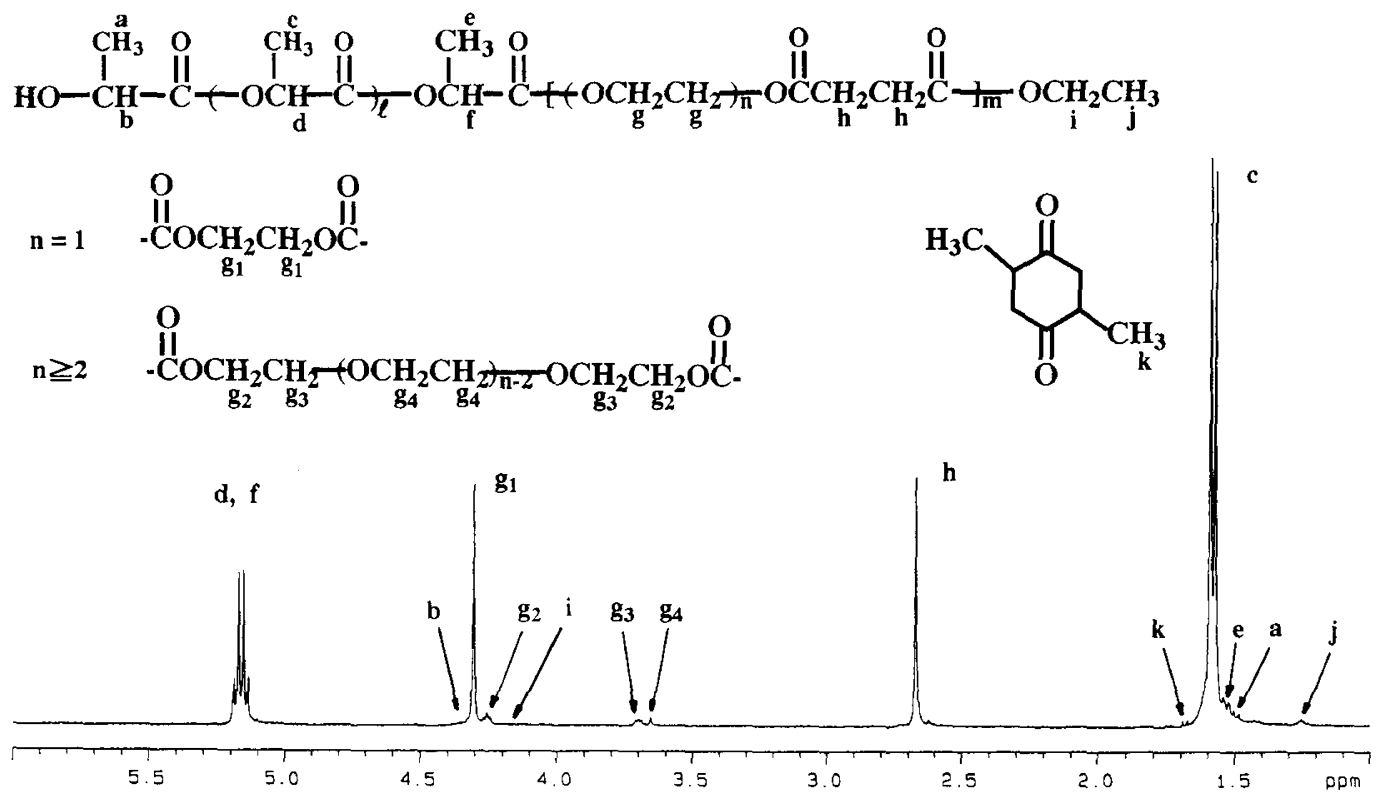

\section{${ }^{13}$ C NMR}

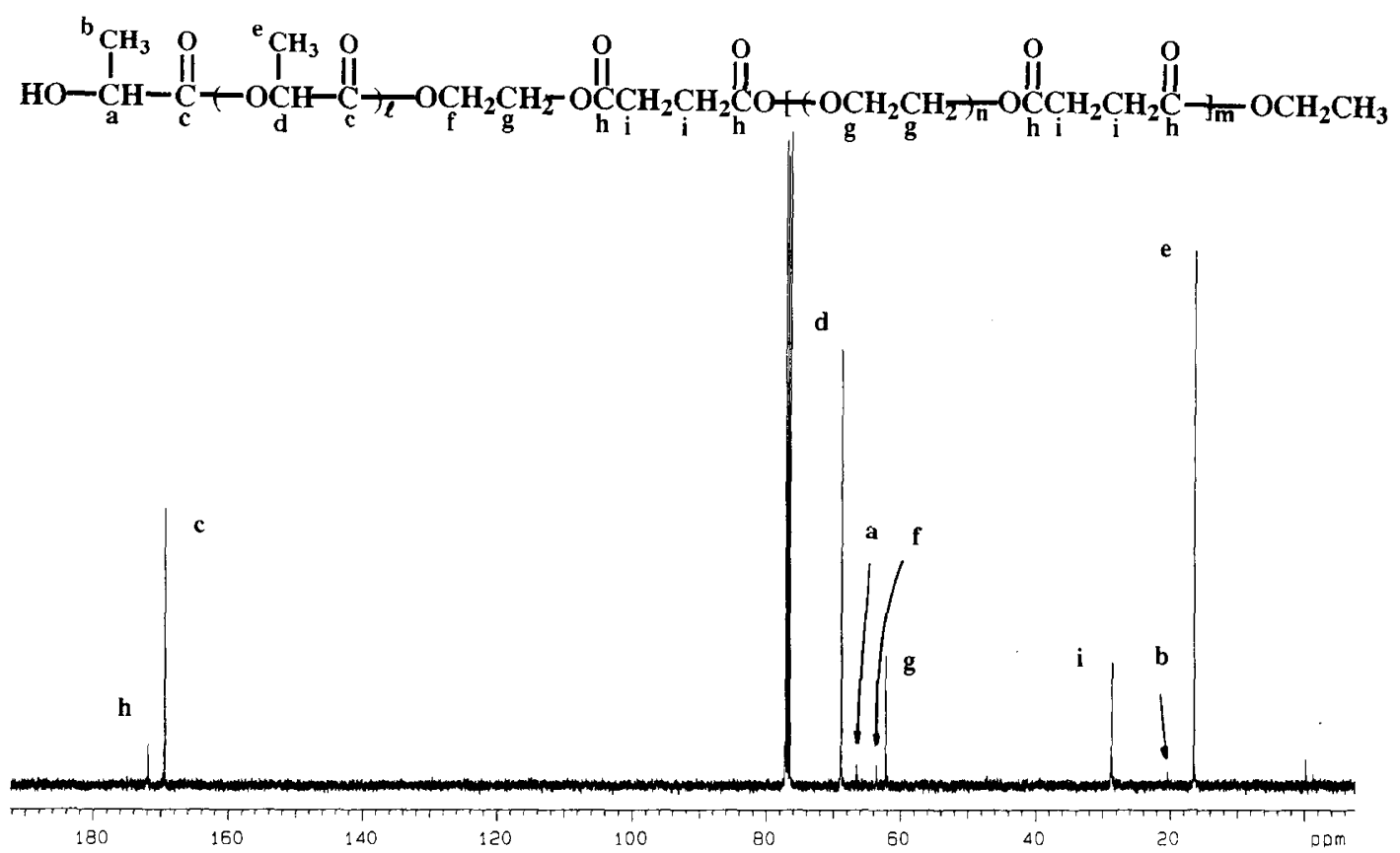

Figure 2. ${ }^{1} \mathrm{H}$ NMR and ${ }^{13} \mathrm{C}$ NMR of copoly(succinic anhydride-ethylene oxide)-poly(L-lactide) block copolymer (Run 3 in Table I) polymerized at feed weight ratio, LA/copoly $(\mathrm{SA}-\mathrm{EO})=1$ for $19 \mathrm{~h}$ at $110^{\circ} \mathrm{C}$.

the coordination compound. We tried to clarify the LA initiation mechanisms in the presence of $\mathrm{Sn}(\mathrm{Oct})_{2}$ and copoly(SA-EO) having one $\mathrm{OH}$-end group on the base of the characterization of block copolymers synthesized under various polymerization conditions. However, the conclusion with respect to LA initiation mechanisms was not confirmed by the experimental results. It is necessary to investigate fundamentally the mechanism of the LA polymerization.

\section{Thermal Properties of Copolymers}

Melting point $\left(T_{\mathrm{m}}\right)$, heat of fusion $(\Delta H)$, and glass transition temperature $\left(T_{\mathrm{g}}\right)$ of the copolymers obtained were determined by DSC first run. Crystallization temperature $\left(T_{\mathrm{c}}\right)$ was obtained from DSC second run. The thermal properties are summarized in Table III. Some representative DSC traces of typical block copolymers are shown in Figure 3.

The DSC first run curve of the copolymer (c in Figure 3 , Run 6 in Table I)) synthesized by LA polymerization in the presence of copoly(SA-EO) and $\mathrm{Sn}(\mathrm{Oct})_{2}$ showed 
Table III. Thermal properties of block copolymers and homo polymers

\begin{tabular}{|c|c|c|c|c|}
\hline \multirow{3}{*}{ Run } & \multicolumn{4}{|c|}{ Thermal propeties } \\
\hline & $T_{\mathrm{m}}^{\mathrm{a}}$ & $\Delta H^{\mathrm{a}}$ & $T_{\mathrm{g}}^{\mathrm{b}}$ & $T_{\mathrm{c}}^{\mathrm{b}}$ \\
\hline & ${ }^{\circ} \mathrm{C}$ & $\mathrm{mJ} \mathrm{mg}^{-1}$ & ${ }^{\circ} \mathrm{C}$ & ${ }^{\circ} \mathrm{C}$ \\
\hline 1 & 172 & 35 & $-13,45$ & 82 \\
\hline 2 & 170 & 24 & $-10,40$ & 78 \\
\hline 4 & 94 & 36 & -9 & $\mathrm{ND}^{\mathrm{c}}$ \\
\hline 5 & 167 & 27 & 30 & 83 \\
\hline 6 & 90,164 & 3,22 & 21 & 80 \\
\hline 7 & 82,159 & 10,7 & 6 & 60,89 \\
\hline 8 & 160 & 30 & 29 & 89 \\
\hline 9 & 154 & 16 & 16 & 100 \\
\hline 10 & 143 & 14 & -4 & $\mathrm{ND}^{\mathrm{c}}$ \\
\hline 11 & 84,89 & 13,1 & 32 & $\mathrm{ND}^{\mathrm{c}}$ \\
\hline 12 & 94,163 & $32,5.2$ & $-13,2$ & $\mathrm{ND}^{\mathrm{c}}$ \\
\hline 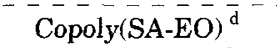 & 96 & $9 \overline{8}$ & $-1 \overline{8}$ & $\overline{-} \overline{2}$ \\
\hline Poly(L-lactide $)^{e}$ & 181 & 42 & 64 & 111 \\
\hline Poly(D,L-lactide $)^{f}$ & ND & ND & 25 & $\mathrm{ND}^{\mathrm{c}}$ \\
\hline Terpoly(SA-EO-LA $)^{g}$ & 79,85 & 5,5 & 25 & $\mathrm{ND}^{\mathrm{c}}$ \\
\hline Blend-1 & 178 & 26 & $-19,57$ & 25,163 \\
\hline Blend-2 & 95,178 & 22,17 & $-17,58$ & $29,69,162$ \\
\hline
\end{tabular}

${ }^{\mathrm{a}}$ Determined by DSC (first run). ${ }^{\mathrm{b}}$ Deternined by DSC (second run). ${ }^{\mathrm{c}}$ Not detected. ${ }^{\mathrm{d}}[\mathrm{SA}] /[\mathrm{EO}]=47 / 53, M_{n}=6700$. ${ }^{\mathrm{e}} M_{n}=$ $24500, M_{w} / M_{n}=2.9 .{ }^{\mathrm{f}} M_{n}=22000, M_{w} / M_{n}=3.3 .{ }^{\mathrm{g}} M_{n}=2500$, $M_{w} / M_{n}=2.8,[\mathrm{SA}] /[\mathrm{EO}] /[\mathrm{L}]=15 / 22 / 63 .{ }^{\mathrm{h}}$ Feed weight ratio, PLA $/$ copoly $(\mathrm{SA}-\mathrm{EO})=75 / 25,[\mathrm{SA}] /[\mathrm{EO}] /[\mathrm{L}]=13 / 17 / 70 .{ }^{\mathrm{i}}$ Feed weight ratio, PLA $/$ copoly $(\mathrm{SA}-\mathrm{EO})=50 / 50, \quad[\mathrm{SA}] /[\mathrm{EO}] /[\mathrm{L}]=28 /$ $33 / 39$.

two endothermic peaks (at $90^{\circ} \mathrm{C}$ and $164^{\circ} \mathrm{C}$ ) derived from crystal fusion of copoly(SA-EO) segment and PLA segment. The endothermic peak derived from copoly(SAEO) segment was broad and small because of overlapping with the exothermic peak of crystallization of PLA segment. The two $T_{\mathrm{m}} \mathrm{s}$ of these copolymers shifted slightly toward lower temperatures because of compatibility of two different segments. $\Delta H$ of PLA segment increased with LA feed ratio. The DSC first run of blend copolymer (weight ratio of PLA to copoly(SA-EO) $=75$ / 25, $\mathbf{a}$ in Figure 3) showed no crystallization peak and had two endothermic peaks derived from crystal fusion of copoly(SA-EO) and PLA segments. $T_{\mathrm{m}} \mathrm{s}$ of the blend copolymer were the same as those of feed homopolymers. Although, the DSC curve of the terpoly(SA-EO-LA) $\left(M_{n}\right.$ $=2500,[\mathrm{SA}] /[\mathrm{EO}] /[\mathrm{LA}]=15 / 22 / 63$, see EXPERIMENTAL section) had two small endothermic peaks. ${ }^{1} \mathrm{H}$ NMR spectra of the terpolymer showed the signal of LA homo sequence $\left(-\mathrm{CH}_{3}\right.$, d., $\left.\delta 1.57 \mathrm{ppm}, J=7.2 \mathrm{~Hz}\right)$. These results support the view that the terpolymer containes a short LA sequence.

$T_{\mathrm{g}}$ of the copolymer synthesized by the ring-opening polymerization of LA in the presence of copoly(SA-EO) and $\mathrm{Sn}(\mathrm{Oct})_{2}$ shifted to the temperature of about $10^{\circ} \mathrm{C}$ lower than those of PLA and the above blend. $T_{\mathrm{g}}$ of the copolymer from DSC second run shifted to a temperature of about $15^{\circ} \mathrm{C}$ lower than that from first run. This was not observed for DSC of PLA and the blend of PLA and copoly(SA-EO).

$T_{\mathrm{c}}$ of the copolymers obtained decreased compared with that of PLA and the blends, suggesting that the rate of crystallization of PLA segment in the copolymer decreases because of block copolymerization.

DSC and GPC measurements and the spectra of ${ }^{1} \mathrm{H}$ NMR and ${ }^{13} \mathrm{C}$ NMR show clearly that the copolymer synthesized by the ring-opening polymerization of LA in

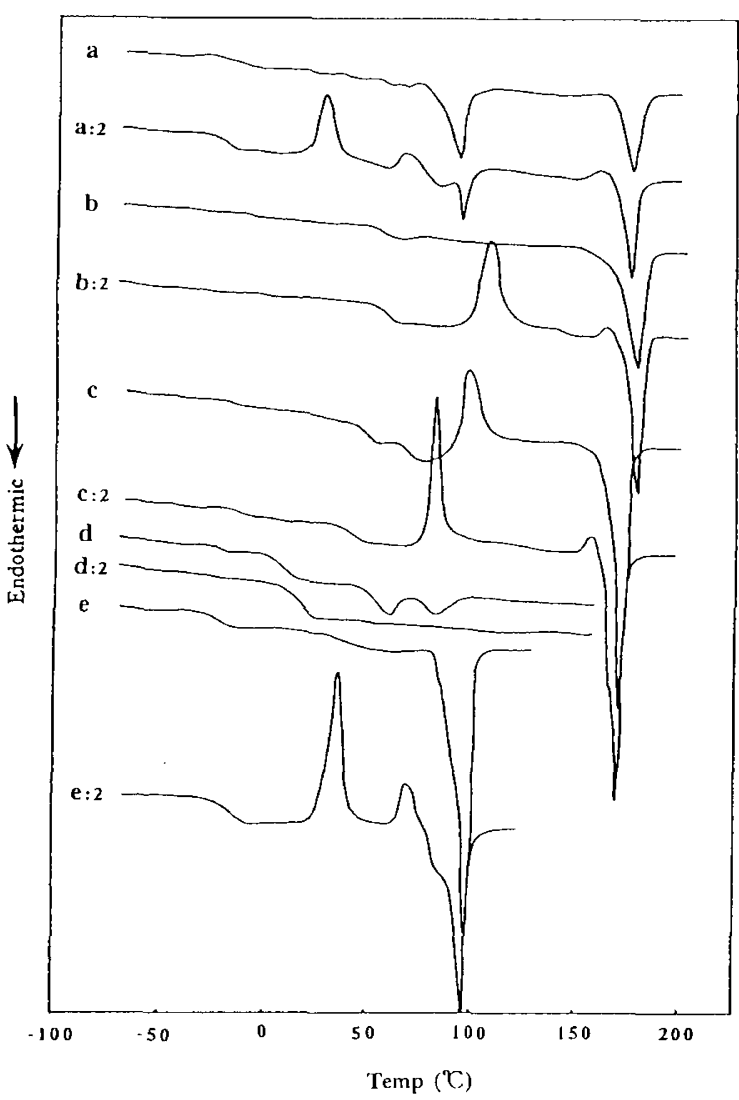

Figure 3. DSC scans of copolymers at a scan rate of $10^{\circ} \mathrm{C} \mathrm{min}{ }^{-1}$ : (a) ; blend[copoly(SA-EO)-PLA], (b) ; PLA (Run 15 in Table I), (c) ; poly[copoly(SA-EO)-block-PLA)] (Run 6 in Table I), (d); terpoly(SA-EO-LA), (e) ; $\operatorname{copoly}(\mathrm{SA}-\mathrm{EO})\left(M_{n}=6700, M_{w} / M_{n}=2.0\right) .2 ; \mathrm{DSC}$ second run.

the presence of copoly(SA-EO) with $\mathrm{Sn}(\mathrm{Oct})_{2}$ is a block copolymer containing PLA segment and copoly(SA-EO) segment.

Figure 4 shows the DSC curves of the block copolymers synthesized by polymerization of LA [feed weight ratio of $\mathrm{LA} /$ copoly $(\mathrm{SA}-\mathrm{EO})=2$ ] in the presence of copoly$(\mathrm{SA} / \mathrm{EO})$ and $\mathrm{Sn}(\mathrm{Oct})_{2}$ at various temperatures and times. DSC curves for the block copolymer synthesized at $110^{\circ} \mathrm{C}$ for $19 \mathrm{~h}$ (Run 2 in Table I) were similar to those of the copolymer synthesized at $145^{\circ} \mathrm{C}$ for $5 \mathrm{~h}$ (Run 6 ). The $T_{\mathrm{m}}$ of the block copolymer synthesized at $145^{\circ} \mathrm{C}$ for 5 h (Run 9) was higher than that of the copolymer synthesized at $110^{\circ} \mathrm{C}$ for $19 \mathrm{~h}$. An increase in $M_{n}$ of the block copolymer turned out to lead to higher $T_{m}$. The endothermic peaks in DSC curves of the block copolymer synthesized at $175^{\circ} \mathrm{C}$ for $2.5 \mathrm{~h}$ were broad and small and shifted to lower temperatures compared to those of block copolymer synthesized under other two different conditions. A transesterification reaction initiated by a temperature rise resulted in a decrease in the $M_{n}$ of the block copolymer. These results and the decrease of SA content of copoly(SA-EO) segment in the block copolymer through LA polymerization (Table I) suggest that a transesterification occurred partially during the polymerization of LA. Increase in reaction temperature promoted the transesterification. This agrees with Ikada et $a l .{ }^{40}$ for the homopolymerization of LA with $\mathrm{Sn}(\mathrm{Oct})_{2}$. However, a transesterification mechanism of the block copolymer in- 


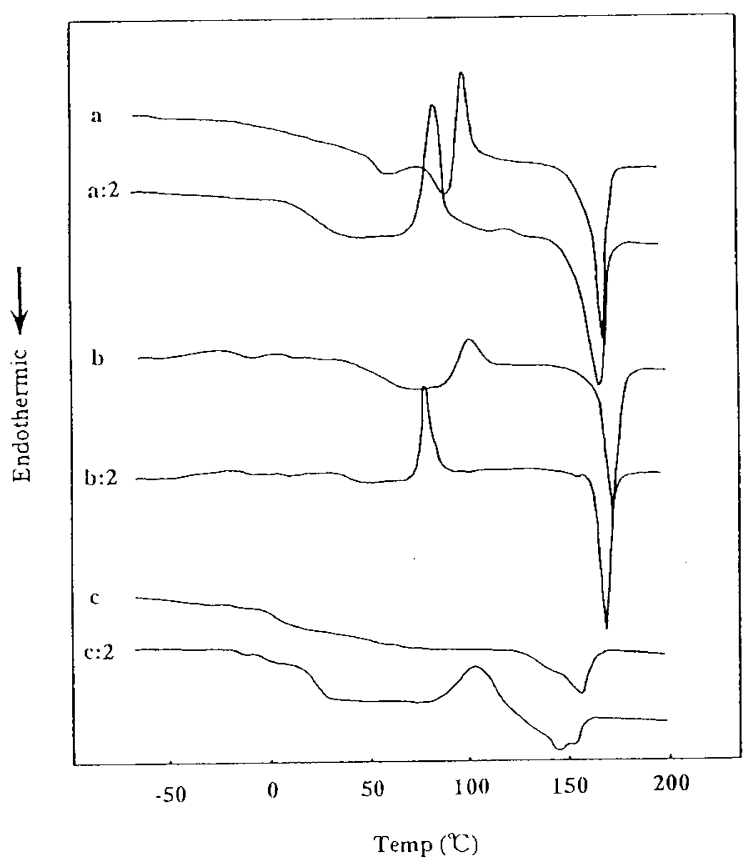

Figure 4. DSC scans of poly[copoly(SA-EO)-block-PLA] : (a); Polymerized at $110^{\circ} \mathrm{C}$ for $19 \mathrm{~h}$ (Run 2 in Table I), (b); polymerized at $145^{\circ} \mathrm{C}$ for $5 \mathrm{~h}$ (Run 6 ), (c) ; polymerized at $170^{\circ} \mathrm{C}$ for $2.5 \mathrm{~h}$ (Run $3)$.

cluding copoly(SA-EO) and PLA segment is not clear.

\section{Morphology of Block Copolymers}

Optical micrographs of block polymer films with PLA and the blend (Blend 1 in Table III) of PLA and copoly(SA-EO) are shown in Figure 5. All polymer films after compression molding (see EXPERIMENTAL section) were rapidly cooled to room temperature and crystallized at $100^{\circ} \mathrm{C}$ for $30 \mathrm{~min}$. PLA (a), the block copolymer $(\mathbf{b}, \mathbf{c})$ and chain-extended copoly $(\mathrm{SA}-\mathrm{EO})^{41}(\mathbf{d})$ showed a spherulitic morphology. Tsuji and Ikada ${ }^{42,43}$ reported that the growth rate and size of spherulite for the as-cast PLA film crystallized at annealing temperature ranging 60 to $100^{\circ} \mathrm{C}$ though quick quenching to $0^{\circ} \mathrm{C}$ after melting the polymer is lower than those for film crystallized at above-mentioned temperature from the melt. The samples studied here were quenched to room temperature from the melt, followed by crystallization at $100^{\circ} \mathrm{C}$ for 1 h. Spherulites in the block copolymer were smaller than $10 \mu \mathrm{m}$ because of a faster polymer crystallization. This agrees with Ikada. ${ }^{41,42}$ The size of spherulite of the block copolymers increased with LA content in the block copolymer. In contrast with copolymers $(\mathbf{a}-\mathbf{c})$, the blend (e) showed phase separation morphology.

\section{Hydrolysis with and without Lipase}

Hydrolysis of these copolymers was carried out with lipase at $37^{\circ} \mathrm{C}$ and without lipase at $70^{\circ} \mathrm{C}$. The samples of copolymers used for hydrolysis were powder, flakes, dried under vacuum at $80^{\circ} \mathrm{C}$ for $24 \mathrm{~h}$ after precipitation with petroleum ether, or film prepared by compression molding (see EXPERIMENTAL section). The results of hydrolysis are summarized in Table IV. Enzymatic hydrolysis of the block copolymer with lipase from Rhizopus arrhizus decreased with increase in LA content in the copolymer. Terpoly(SA-EO-LA) containing 63 (a)
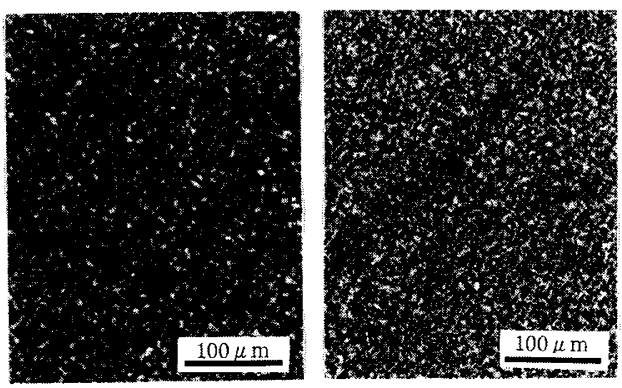

(b) (c)

(e)
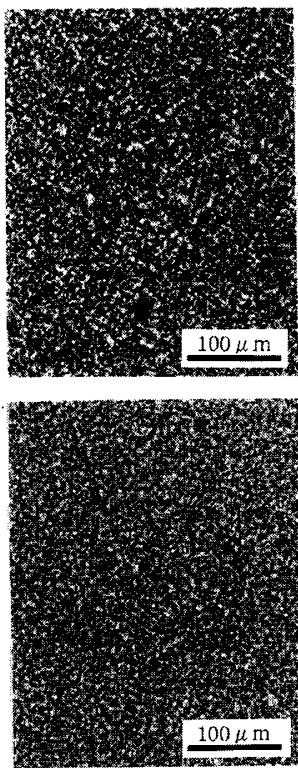
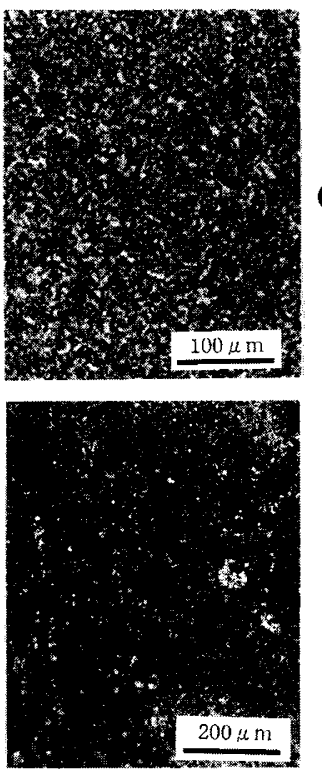

Figure 5. Optical photomicrographs of polymer films crystallized isothermally at $100^{\circ} \mathrm{C}$ for $30 \mathrm{~min}$ after quenching to room temperature from the melts : (a); PLA, $M_{n}=22000$, (b); block copolymer, $M_{n}=8100$, [L]/[copoly(SA-EO) $]=35 / 65$ (Run 7 in Table I), (c) ; block copolymer, $M_{n}=11600,[\mathrm{~L}] /[\operatorname{copoly}(\mathrm{SA}-\mathrm{EO})]=54 / 46$ (Run 6), (d) ; block copolymer, $M_{n}=19400,[\mathrm{~L}] /[\operatorname{copoly}(\mathrm{SA}-\mathrm{EO})]=62 / 39$ (Run 5), (e) ; chain-extended copoly(SA-EO) ${ }^{41}, M_{n}=47500$, [SA]/ $[\mathrm{EO}]=47 / 53$, (f) ; blend copolymer of copoly(SA-EO) and PLA (weight ratio of PLA/copoly $(\mathrm{SA}-\mathrm{EO})=75 / 25)$ (Blend-1 in Table III).

molar\% of LA was hydrolyzed with lipase because of the short LA length. The hydrolyzability of the block copolymer synthesized using $\mathrm{AlEt}_{3}$ as a catalyst (Run 12 in Table I) was higher than for other block copolymers.

Block copolymers were hydrolyzed without lipase at $70^{\circ} \mathrm{C}$. The hydrolyzability of the block copolymer increased with decrease in LA content in the copolymer and $M_{n}$ of PLA segments.

The hydrolyzability of the films was low compared with flake or powder samples. This suggests that the hydrolysis of the block copolymer occurs mainly at the polymer surface and the latter influences polymer hydrolyzability.

\section{Biodegradation with Activated Sludge}

The relationships of the biodegradation of typical block copolymers versus time are shown in Figure 6 . The degradability decreased with increase in $M_{n}$ of PLA segment and LA molar content in the block copolymers. In particular, the block copolymer (Run 7 in Table I) having long LA was not degraded by activated sludge within the testing period. These results are in agreement with enzymatic hydrolysis by lipase from Rhizopus arrhizus. 
Table IV. Hydrolyzability of block copolymers and homo polymers with or without lipase

\begin{tabular}{|c|c|c|c|c|}
\hline \multirow{3}{*}{ Run } & \multicolumn{4}{|c|}{ Hydrolyzability, TOC/ppm } \\
\hline & \multicolumn{2}{|c|}{ With lipase $^{a}$} & \multicolumn{2}{|c|}{ Without lipase $^{\text {b }}$} \\
\hline & $\begin{array}{l}\text { Powder } \\
\text { or flake }\end{array}$ & Film $^{d}$ & $\begin{array}{l}\text { Powder } \\
\text { or flake }\end{array}$ & Film $^{d}$ \\
\hline 1 & 55 & - & - & - \\
\hline 2 & - & - & 910 & - \\
\hline 4 & - & - & 840 & - \\
\hline 5 & 40 & 30 & 520 & 350 \\
\hline 6 & 90 & 90 & 740 & 420 \\
\hline 7 & 220 & - & 1130 & 790 \\
\hline 11 & 50 & - & - & - \\
\hline 12 & 350 & - & - & - \\
\hline Copoly(SA-EO) ${ }^{\mathrm{e}}$ & 150 & - & 340 & - \\
\hline Poly $(\text { L-lactide })^{f}$ & 2 & 1 & 120 & 40 \\
\hline Poly(D,L-lactide $)^{\mathrm{g}}$ & 1 & - & - & - \\
\hline Terpoly(SA-EO-LA) $^{\text {h }}$ & 670 & - & - & - \\
\hline Blend- ${ }^{\mathrm{i}}$ & 25 & 30 & 180 & 170 \\
\hline Blend- $2^{j}$ & 80 & - & 250 & - \\
\hline
\end{tabular}

${ }^{a}$ At $37^{\circ} \mathrm{C}$ for 1 day. Lipase (1250U) from Rhizopus arrhizus was added. ${ }^{\mathrm{b}}$ At $70^{\circ} \mathrm{C}$ for 5 days. ${ }^{\mathrm{c}}$ Polymer sample after precipitated with petroleum ether was used. ${ }^{d}$ Film was prepared by compression molding. Molding was carried out at a temperature of about $5^{\circ} \mathrm{C}$ higher than the melting point of the polymer for 1 min. ${ }^{\mathrm{e}}[\mathrm{SA}] /[\mathrm{EO}]=47 / 53, M_{n}=6700 .{ }^{\mathrm{f}} M_{n}=24500, M_{w} / M_{n}=$ 2.9. ${ }^{\mathrm{g}} M_{n}=22000, M_{w} / M_{n}=3.3 .{ }^{\mathrm{h}} M_{n}=2500, M_{u} / M_{n}=2.8$, $[\mathrm{SA}] /[\mathrm{EO}] /[\mathrm{L}]=15 / 22 / 63 .{ }^{2}$ i Feed weight ratio, PLA/copoly(SA$\mathrm{EO})=75 / 25,[\mathrm{SA}] /[\mathrm{EO}] /[\mathrm{L}]=13 / 17 / 70 .{ }^{\mathrm{j}}$ Feed weight ratio, $\mathrm{PLA} / \mathrm{copoly}(\mathrm{SA}-\mathrm{EO})=50 / 50,[\mathrm{SA}] /[\mathrm{EO}] /[\mathrm{L}]=28 / 33 / 39$

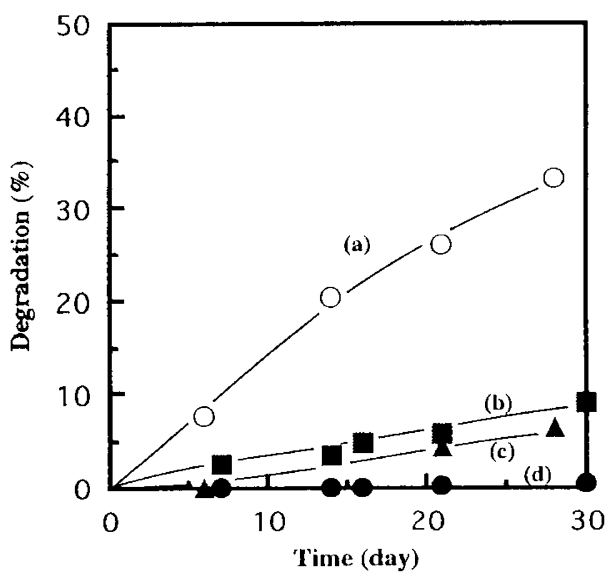

Figure 6. Biodegradation of typical copolymers by standard activated sludge at $30^{\circ} \mathrm{C}:(\mathrm{a}) ; M_{n}=7800,[\mathrm{~L}] /[\operatorname{copoly}(\mathrm{SA}-\mathrm{EO})]=47 / 53$ molar ratio (Run 12 in Table I), (b) ; $M_{n}=11600$, [L]/ [copoly(SAEO) $]=35 / 65$ molar ratio (Run 6), (c) $; M_{n}=12300$, [L]/ [copoly(SA$\mathrm{EO})]=69 / 31$ molar ratio (Run 1), (d); $M_{n}=19400,[\mathrm{~L}] /[\operatorname{copoly}(\mathrm{SA}-$ EO) $=62 / 38$ molar ratio (Run 5). The film samples (ca. $50 \mu \mathrm{m}$ thick) were prepared by compression molding.

Table V. Solubility of block copolymers in THF or in $\mathrm{THF} / \mathrm{CHCl}_{3}$

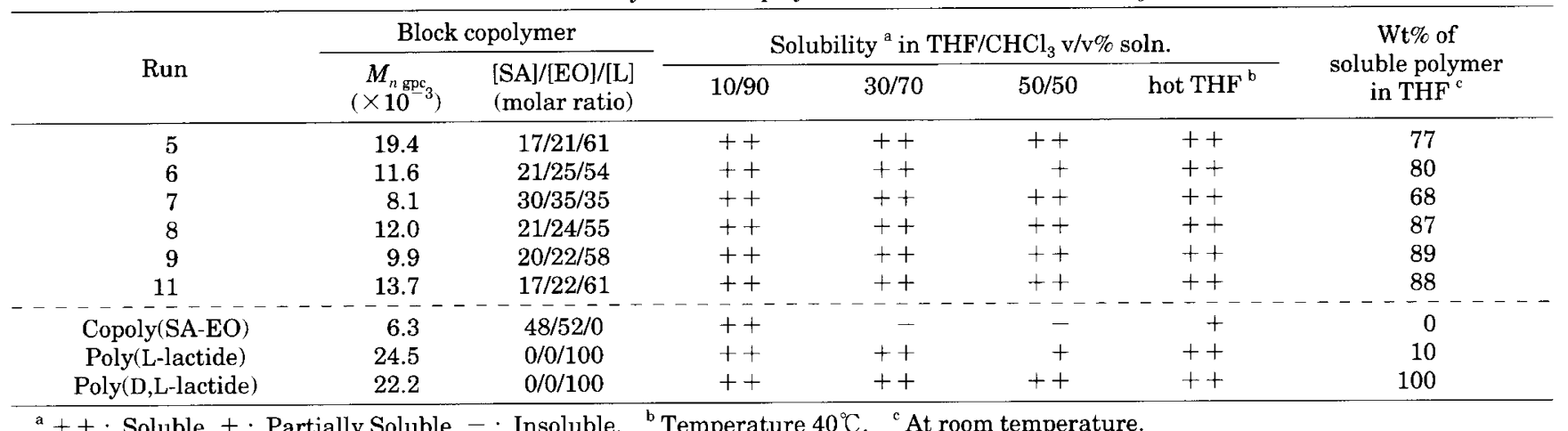

TOC of the medium in the incubator filtered by $5 \mathrm{~A}$ filter paper was measured using a TOC analyzer (see ExPERIMENTAL section) to determine the water-soluble compounds produced after degradation by activated sludge. TOC were below $2 \mathrm{ppm}$ in all cases measured. This indicates that the water-soluble compounds produced by the hydrolysis of block copolymers are rapidly converted into $\mathrm{CO}_{2}$ and $\mathrm{H}_{2} \mathrm{O}$.

\section{Solubility in THF and in a Different Mixture of THF/ $\mathrm{CHCl}_{3}$}

The solubility of the block copolymers and homo polymers in THF and a different mixture of $\mathrm{THF} / \mathrm{CHCl}_{3}$ is given in Table $\mathrm{V}$. All block copolymers and copolymers, except copoly(SA-EO) used as a prepolymer were soluble in hot THF $\left(40^{\circ} \mathrm{C}\right)$. The block copolymers and PLA were partially soluble in THF at room temperature. The solubility of block copolymers in THF increased with an increase in LA content in the block copolymers. In comparison with the solubility for Run 7 (or Run 8) and Run
10 (or Run 13), the solubility for the former was greater than that for the latter in spite of equivalent LA content. Small length of copoly(SA-EO) segment in the block copolymer with rise in polymerization temperature $\left(170^{\circ} \mathrm{C}\right)$ resulted in greater solubility compared to that of the polymer prepared at low temperature $\left(145^{\circ} \mathrm{C}\right)$, considering the DSC results of the block copolymers. Copoly(SAEO)s having high SA content of 46 to $49 \mathrm{~mol} \%$ were soluble only in organic chlorinated solvents such as $\mathrm{CHCl}_{3}$. The block copolymerization of copoly(SA-EO) with PLA brought about higher solubility in THF and in a mixture of $\mathrm{THF}$ and $\mathrm{CHCl}_{3}$.

\section{CONCLUSIONS}

The copoly(SA-EO)-PLA block copolymers were synthesized by a ring-opening polymerization of LA in presence of $\mathrm{Sn}(\mathrm{Oct})_{2}$ and copoly(SA-EO) having SA content 47 or $48 \mathrm{~mol} \%$ and hydroxyl group at one end of the copolymer. $M_{n}$ of the synthesized block copolymer in- 
creased with LA feed weight ratio. Copoly(SA-EO) was slightly decomposed during the LA polymerization. Micrographs of the copolymer films showed spherulitic morphology. Spherulite size became greater with higher LA content in the copolymers. The block copolymers were hydrolyzed with or without lipase and degraded in the presence of enzyme from microorganisms in activated sludge. The hydrolyzability decreased with increase in LA content in the block copolymers. The solubility of the block copolymers containing LA segment in THF was higher than that of copoly(SA-EO). However, the flexibility of PLA could not be improved because of fine crystallinity of copoly(SA-EO) segment having higher SA content. It is expected that PLA may change to soft and biodegradable material by a block polymerization of PLA with copoly(SA-EO) having lower SA content, e.g., $40-42 \mathrm{~mol} \%$.

\section{REFERENCES AND NOTES}

1. Y. Tokiwa and T. Suzuki, Nature, 270, 76 (1977).

2. E. Takiyama and T. Fujimaki, "Biodegradable Plastics and Polymer", Vol.12, Y. Doi and K. Fukuda, Ed., Elsevier, Amsterdam, 1994, session 3, pp 150-174.

3. H. Fukuzaki, M. Yoshida, M. Asano, Y. Aiba, and I. Kaetsu, Eur. Polym. J., 24, 1029 (1988).

4. M. S. Reeve, S. P. MaCarthy, M. J. Downey, and R. A. Gross, Macromolecules, 27, 825 (1994).

5. J. Xu, R. A. Gross, D. L. Kaplan, and G. Swift, Macromolecules, 29, 3857 (1996).

6. A. Park and L. G. Cima, J. Biomed. Master. Res., 31, 117 (1996).

7. I. Arvanitoyannis, A. Nakayama, N. Kawasaki, and N. Yamamoto, Polymer, 36, 2947 (1995).

8. I. Arvanitoyannis, A. Nakayama, N. Kawasaki, and N. Yamamoto, Polymer, 36, 2271 (1995).

9. I. Arvanitoyannis, A. Nakayama, E. Psomiadou, N. Kawasaki, and N. Yamamoto, Polymer, 37, 651 (1996).

10. V. S. Livshits and G. E. Zaikov, Int. J. Polym. Mater., 16, 267 (1992).

11. L. M. Sanders, G. I. McRae, K. M. Vitale, and B. A. Kell, J. Controlled Release, 2, 187 (1995).

12. R. A. Kenley, M. O. Lee, T. R. Mahoney, II, and L. M. Sanders, Macromolecules, 20, 2398 (1987).

13. K. Jamshidi, R. C. Eberhart, S. H. Hyon, and Y. Ikada, Polym. Prepr., Am. Chem. Soc., Div. Polym. Chem., 28, 236 (1987).

14. H. R. Kricheldorf and J. Meier-Haack, Makromol. Chem., 194, 715 (1993).

15. D. Cohn and H. Younes, J. Biomed. Mater. Res., 22, 993 (1988).

16. D. K.Han and J. A. Hubbell, Macromolecules, 30, 6077 (1997).

17. C. W. Lee and Y. Kimura, Bull. Chem. Soc., Jpn., 69, 1787 (1996).
18. X. Chen, S. P. McCarthy, and R. A. Gross, Macromolecules, 30, 4295 (1997).

19. S. M. Li, I. Rashkov, J. L. Espartero, N. Manolova, and M. Vert, Macromolecules, 29, 57 (1996).

20. I. Rashkov, N. Manolova, S. M. Li, J. L. Espartero, and M. Vert, Macromolecules, 29, 50 (1996).

21. J. Mahammadi-Rorshandeh, S. M. F. Farnia, and M. N. Sarbolouki, J. Appl. Polym. Sci., 68, 1949 (1998).

22. Y. J. Du, P. J. Lemstra, A. J. Nijenhuis, H. A. M. van Abert, and G. Bastiaansen, Macromolecules, 28, 2124 (1995).

23. W. M. Stevels, A. Bernard, P. Van De Witte, P. J. Dijkstra, and J. Feijen, J. Appl. Polym. Sci., 62, 1295 (1996).

24. W. M. Stevels, M. J. K. Ankone, J. Dijkstra, and J. Feijan, Macromol. Chem. Phys., 196, 1153 (1995).

25. P. J. A. Int Veld, E. M. Velner, P. Van De Witte, P. J. Dijkstra, and J. Feijen, J. Polym. Sci., Part A, Polym. Chem., 35, 219 (1997).

26. C. X. Song and X. D. Feng, Macromolecules, 17, 2764 (1984).

27. X. J. Feng, C. X. Song, and W. Y. Chen, J. Polym. Sci., Polym. Lett. Ed., 21, 593 (1983).

28. E. J. Choi, J. K. Park, and H. N. Chang, J. Polym. Sci., Polym. Phys., 32, 2481 (1994).

29. D. W. Grijpma and A. J. Pennings, Polym. Bull., 25, 335 (1991).

30. P. Vanhoorne, Ph. Dubois, R. Jerome, and Ph. Teyssie, Macromolecules, 25, 37 (1992).

31. M. S. Reeve, S. P. McCarthy, and R. A. Gross, Macromolecules, 26, 888 (1993).

32. Y. Maeda, A. Nakayama, N. Kawasaki, K. Hayashi, S. Aiba, and N. Yamamoto, Polymer, 38, 4717 (1997).

33. Y. Maeda, A. Nakayama, N. Kawasaki, K. Hayashi, S. Aiba, and N. Yamamoto, Polym. J., 29, 836 (1997).

34. Y. Maeda, K. Sakai, A. Nakayama, N. Kawasaki, I. Arvanitoyannis, K. Hayashi, S. Aiba, and N. Yamamoto, J. Appl. Polym. Sci., 68, 2095 (1998).

35. Y. Maeda, A. Nakayama, I. Arvanitoyannis, N. Kawasaki, K. Hayashi, S. Aiba, and N. Yamamoto, J. Appl. Polym. Sci., 69. 303 (1998).

36. S. J. Huang, P. G. Edelman, and J. A. Cameron, Polym. Sci., Technol., 35, 101 (1987).

37. Y. Maeda, A. Nakayama, N. Kawasaki, K. Hayashi, S. Aiba, and N. Yamamoto, J. Environ. Polym. Degrad., 4, 225 (1996).

38. H. R. Kricheldorf, I. Kreiser-Saunders, and C. Boettchen, Polymer, 36, 1253 (1995).

39. A. J. Nijenhuis, D. W. Grijpma, and A. J. Pennings, Macromolecules, 25, 6419 (1992).

40. K. Jamshidi, R. C. Eberhart, S. H. Hyon, and Y. Ikada, Polym. Prepr., Am. Chem. Soc., Div. Polym. Chem., 28, 236 (1987).

41. Chain-extension reaction of copoly(SA-EO) was carried out as follows: The copolymer $(3 \mathrm{~g})$ was placed in a $100 \mathrm{~mL}$ threenecked flask equipped with a stirrer. After the copolymer was molten by heating, titanium tetra-iso-propoxide $(0.025 \mathrm{~g})$ was added and the mixture was kept stirring under vacuum at $170^{\circ} \mathrm{C}$ for $4-12 \mathrm{~h}$.

42. H. Tsuji and Y. Ikada, Polymer, 36, 2709 (1995).

43. H. Tsuji and Y. Ikada, J. Appl. Polym. Sci., 58, 1793 (1995). 